\title{
Erratum to: The Development of In-Service Science Teachers' Understandings of and Orientations to Teaching the Nature of Science within a PCK-Based NOS Course
}

\section{Chatree Faikhamta}

Published online: 5 January 2013

(C) Springer Science+Business Media Dordrecht 2012

\section{Erratum to: Res Sci Educ (2012) \\ DOI 10.1007/s11165-012-9283-4}

The original version of this article unfortunately contained a mistake. The spelling of the bibliographic information of "Hanuscin, D. L., Lee, M. H., \& Akerson, V. L. (2011). Elementary teachers' pedagogical content knowledge for teaching the nature of science. Science Education, 95, 145-167." and its citations were incorrectly spelled to "Haunscin et al. 2011".

The online version of the original article can be found at http://dx.doi.org/10.1007/s11165-012-9283-4.

C. Faikhamta $(\bowtie)$

Faculty of Education, Kasetsart University, 50 Ngamwongwan Rd., Chatuchak,

Bangkok 10900, Thailand

e-mail: chatreechem@yahoo.com 